\title{
DIVIDEND PAYOUT RATIO: FACTORS THAT AFFECT IT, AND SUBSEQUENT EARNING GROWTH
}

\author{
Antoni Susanto ${ }^{1}$ \\ ERION Computer \\ Junius Tirok ${ }^{2}$ \\ BINUS Business School
}

\begin{abstract}
This paper is to investigate the determinants of the Dividend Payout Ratio (DPR) of Indonesian firms. Five factors (maturity, cash availability, leverage, profitability, firm size) are analyzed as the DPR determinants. Additionally, this thesis also examines the ability of DPR to serve as a signal subsequent year's earnings growth. Multiple regression models is used in this paper to analyze research sample that consists of 180 firms that are listed in Indonesia Stock Exchange (IDX) and paid dividends during 2003-2008. The results shows that cash availability and maturity are significant determinants of DPR. Further analysis shows that the DPR signals subsequent earnings growth, the result concludes that mature firms has high dividend payment ratio, which supports firm lifecycle theory. High DPR results in high subsequent earnings growth, which supports Black's (1976) claim that DPR carries information on future growth.
\end{abstract}

Keywords: Indonesian stock exchange, dividend payout ratio, returns on assets, debt to equity ratio, firm size, maturity, subsequent earnings growth.

\section{BACKGROUND}

The financial market, especially stock market, has long become the crucial part of the industry where firms can raise fund for their further

\footnotetext{
${ }^{1}$ ERION Computer (vins_cassie@yahoo.com).

${ }^{2}$ Faculty of Business, BINUS Business School (jtirok@hotmail.com).
} 
investments. However, without investors involved in the market, there will be no fund. In order to attract investors, firms have to create real value so that it can give return to the investor and become attractive investment. This is the essential of corporate finance: maximizing the corporate value that eventually will give return to the investors. One way to realize return to the investors as shareholders is by giving out dividend.

Dividend may come as cash dividend or stock dividend. As cash dividends are much more prevalent, in this thesis focus will be made on cash dividend thus the word 'dividend' simply means 'cash dividend'. The problem with dividend is that, it's taken from the profit of the firm which would be otherwise reinvested. With this in mind, it's very crucial to balance between reinvestment and dividend payment. The phrase 'dividend policy' deals with this issue. Dividend policy is important to ensure that the proportion of dividend is optimal in maximizing the company's value.

Miller and Modigliani (1961) put an emphasis on the importance of dividend policy to corporate officials who made dividend-related decisions, to investors who construct their portfolio, and economists who seek to understand and appraise the capital market function. For corporate officials, dividend policy will affect the ability of the company to get into more investments. The more the earnings are retained, the more possibility for the company to engage into investments without requiring more fund from financial institutions which is cost and interest-bearing. As Black (1975) stated, the cost of underwriting new debt and equity may be as large as several percent of the debt/equity, while the company incurs no cost at retaining the earnings. However, the decision on how much of the earnings to be distributed as dividend is still a wide argument among researchers. For investors in constructing their portfolio, it's crucial to know whether a dividend-paying company stock has higher expected future growth (Arnott and Asness, 2003). Higher future growth means a better performance company which translates to higher value. Another interview study by Baker, Farelly, and Edelman (1985) also signifies the importance of dividend policy for investors. The study found out that majority of the managers believes that investors care about whether their return comes from dividend or capital gain. 
In the sense of stock market securities investments, some proponent of dividend payment argued that dividend should be paid as a true return of investment made by investors, regardless of double-taxation and capital gain on stocks. However, some against dividend payment viewing that management's motive to pay dividend is a sign of lack of ideas worth investment. These arguments boil down to one question: does dividend payment relevant to the corporate value? According to Brealey and Myers (2002), researches still have to be done theoretically and empirically to reach a consensus to answer the question, or as Black (1975) coined "dividend puzzle".

Several theories surrounding the dividend payment has been proposed. Miller and Modigliani (1961) proposed the famous dividend irrelevance theory. This theory states that dividend is irrelevant as investors who prefer dividend payment can convert portion of their holding to cash to mimic cash received from dividend payment. This theory assumed markets to be perfect: zero transaction cost and tax, rational investor behavior, and no information asymmetry between investor and management. The implication of this theory is that, because of irrelevance of dividend payment, firms may begin to stop giving out dividend as it can be home-made by investors.

Another theory also proposed by Wurgler and Baker (2004) called Catering Theory of Dividends states that dividend policies are based on the investor's demand. When investors are valuing dividendpaying firms higher than non-dividend-paying firms, the managers will initiate dividend payment, and vice versa. Further studies by Wurgler and Baker (2004) also found an interesting fact that the propensity to pay dividend decrease when there's growth stock booming (in times of new technology ages, for example). The propensity to pay dividends also increases after the bust of those stocks, thus confirming their theory. This theory does not contradict the irrelevance theory. According to Wurgler et al, when the rational market assumption of the irrelevance theory are taken out, dividend policy is relevant to counteract the security mispricing.

In his paper titled "A Life Cycle Theory of the Firm”, Mueller (1972) argued that reinvestments are large in the early days of the firm (growth stage). He asserted that newly-born enterprises tend to have 
more ideas for investments thus requiring the firm to retain most of its earnings. As the firm matures, innovation potential declines and increasing portion of profits goes into dividend payment. This argument set forth another research by DeAngelo, DeAngelo, and Stulz (2006) to test the validity of such claim. DeAngelo et al. (2006) uses several variables as a function of the propensity to pay dividend. Among the variables used including: Earned Equity to Total Common Equity (RE/TE) ratio as the measure of maturity, Return on Asset (ROA) as the measure of profitability, Cash to Total Asset as Cash Position, NYSE Equity Percentile as the measure of size. Their findings are consistent with the life cycle theory: all evidence supports the life cycle theory of dividend assuming the life cycle is reflected on the mix of its equity capital.

From the grounding of previous researches in the dividend policy field, we'd like to find out how dividend payment ratio (as a part of dividend policy) may be affected by several variables. We'd like also to find out whether dividend payout ratio may affect the subsequent earning growth of the firm as an extension to the research Arnott and Asness (2003) have done before using U.S. Markets data.

Practically, from the stock market investor point of view, dividend has several advantages and disadvantages. A typical investor or fund manager would construct a portfolio that really reflects their investment needs. Question arises in portfolio management: could dividend payout ratio explain the subsequent earnings growth of a firm? And what are the acceptable determinants of dividend payout ratio?

In this study, we would like to explore data from Indonesian public listed companies to find out more to answer the questions. Our expectation is to be able to find several answers that will also contribute a puzzle piece for the quest of completing the "dividend puzzle".

\section{Problem Definition}

Issues that will be addressed in this research are:

1. How Firm Size, Cash balance, Leverage, Profitability, and Firm Maturity can determine the dividend payout ratio of a firm. 
2. How dividend payout ratio of year $t$ of a firm can determine the subsequent year's $(t+1)$ earnings growth of the firm.

\section{THEORETICAL BACKGROUND}

Miller and Modigliani (1961) came up with their dividend irrelevance theories. This theory said that dividend policy is irrelevant under perfect market. Perfect market as defined by Keown, Martin, Petty and Scott (1999): (1) no transaction cost, investors can purchase or sell stocks without any fees and companies can issue debt/equity without any cost; (2) no information asymmetry between the outsider and insider of the firm; (3) no financial distress and bankruptcy cost; (4) no taxes; and (5) no conflict of interest between shareholder and managers/agency cost. Thus the value of a firm is independent from any dividend policy made by the management. However, the limitation to this theory is that, market imperfection exists. Currently most countries have taxes regarding dividend and capital gain, transaction cost also exists, and information asymmetry does exist between insider and outsider of the firm.

In their study with data from NYSE, AMEX, and NASDAQ firms, Fama and French (2001) conclude that firm size and profitability positively influences dividend payments while market to book ratio negatively influences dividend payment. In another study, DeAngelo, DeAngelo, and Stulz (2006) found that ratio of Retained Earning to Shareholder's Equity (RE/TE) positively influence the propensity to pay dividend. The RE/TE variable is used to measure a firm's maturity, which higher Retained Earnings in the equity is an indicator of higher firm maturity.

Wurgler and Baker (2004) proposed another theory which uses market characteristic to describe dividend payment. The theory is called Catering Theory of Dividends, stating that dividend policies are based on the investor's demand. When investors are valuing dividendpaying firms higher than non-dividend-paying, the managers will initiate dividend payment, and vice versa. Further studies by Wurgler and Baker (2004) also found an interesting fact that the propensity to pay dividend decrease when there's growth stock booming (in times of new technology ages, for example). The propensity to pay 
dividends also increases after the bust of those stocks (when the market values mature firms more than growth), thus confirming their theory. This research did provide answer to several questions laid out by Black (1976) regarding how the companies can be certain on what the shareholders want.

In 1972, Mueller proposed firm life cycle theory. According to Mueller, a firm was created to exploit the 'Schumpeterian innovation' involving new products, process, marketing or organizational techniques. If the innovation proves to be viable, the firm will expand. The idea would get proven and uncertainty around it would start to diminish. During this growth period, shareholders would want all capitals and also probably all the profits are reinvested to take advantage of the new idea. It may also need to raise more capital from outside to capitalize the idea to wider market. Competition will start and flourish; as it does, the company will begin to improve and new innovation to the product adopted. The market will eventually saturate and profit opportunity begins to decline. In this period the shareholders would not advantage from reinvestment because profit opportunities declines. A stockholder maximizing manager would pay more dividends rather than reinvest it. The life cycle theory suggests that the more mature the firm, the more it pays dividend. As the theory suggests, higher proportion of the retained earnings will indicate a more mature firm. The firm started to accumulate retained earnings from the early and growth stage. At the maturity stage, the firm may have a large portion of retained earnings in the equity.

\section{RESEARCH METHODOLOGY}

This research uses regression analysis to infer from the annual dividend payment data. The data are picked randomly from year 2003 to 2008, with 30 samples taken each year. The dividend payment data for each year is recorded in Indonesian Stock Exchange Book of Statistics. In summary, the model looked like in Figure 1. This research will investigate the relationship between ROA, CASH, SIZE, DER and RETE to DPR, and between DPR to SEG. 


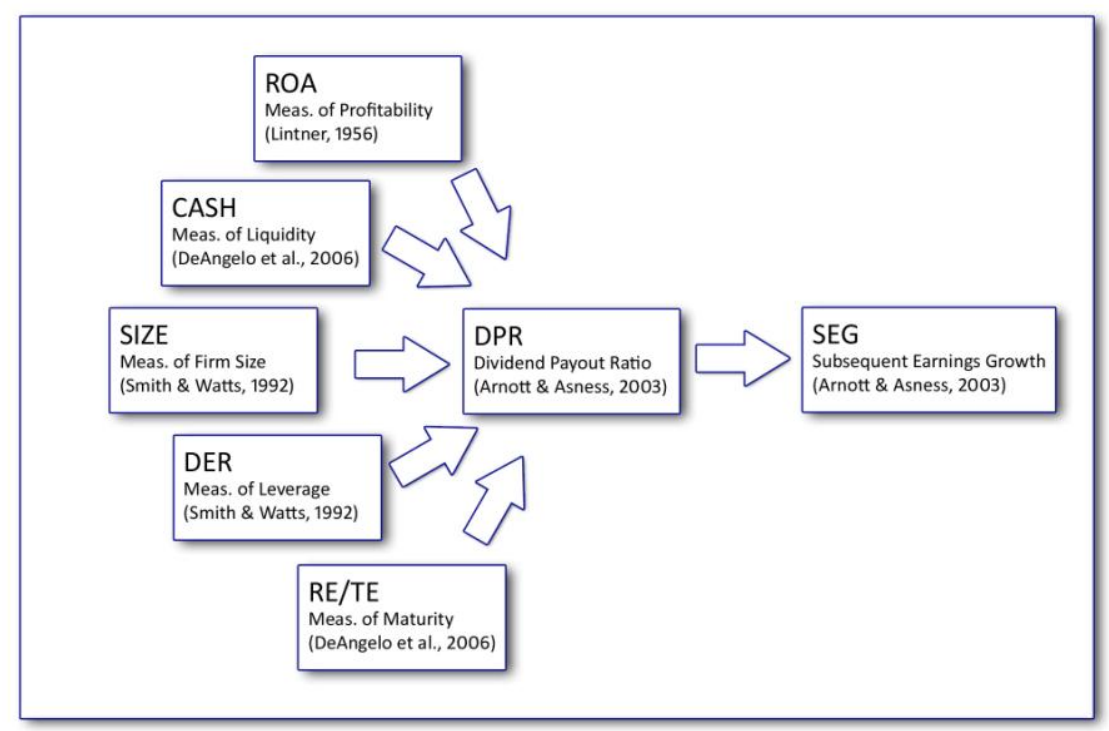

Figure 1. Model of Analysis

Variables involved in this research are:ROA, is the Return on Assets of a company. The values are in percentage, with the equiation given:

$$
\text { ROA }=\frac{\text { Net Income }}{\text { Total Assets }} \times 100 \%
$$

1. CASH, is the ratio of Cash and Equivalents of a company to its Total Asset. The values are in ratio. The equation given:

$$
\text { CASH }=\frac{\text { Cash and Equivalents }}{\text { Total Assets }}
$$

2. SIZE is the measure of firm size, with equation:

$$
\text { SIZE }=\text { Ln(Total Assets) }
$$

3. DER is the Debt to Equity Ratio of the firm. Values in ratio, the equation given:

$$
\text { DER }=\frac{\text { Total Debt }}{\text { Shareholder's Equity }}
$$

4. RE/TE or RETE is the Retained Earnings to Total Shareholder's Equity ratio, as a measure of Maturity. The equation given:

$$
\text { RETE }=\frac{\text { Retained Earnings }}{\text { Shareholder's Equity }}
$$

5. DPR is the Dividend Payout Ratio of a firm, values in ratio. The equation given: 


$$
D P R=\frac{\text { Dividend per Share }}{\text { Earnings per Share }}
$$

6. SEG is the Subsequent Earnings Growth of the firm, values in ratio. The equation given:

$$
S E G_{t+1}=\frac{\text { Earning }_{t+1}}{\text { Earning }_{t}}-1
$$

This research consists of two models. Model 1 is presented below:

$$
D P R_{t}=a+b_{1} \text { CASH }_{t}+b_{2} R E T E_{t}+b_{3} S I Z E_{t}+b_{4} D E R_{t}+b_{5} R O A_{t}+e
$$

Model 2 tests whether DPR has influence on subsequent earnings growth.

$$
S E G_{t+1}=a+b_{1} D P R_{t}+e
$$

There will be 180 samples taken from Book of Statistics that will be used in this study. Hypotheses presented below:

$\mathrm{H}_{1 \mathrm{a}}$ : Firm Size, Cash Balance, Leverage, Profitability, and Firm Maturity are significant determinant of DPR.

$\mathrm{H}_{1 \mathrm{~b}}$ : Firm Size, Cash Balance, Leverage, Profitability, and Firm Maturity are not the determinant of DPR.

$\mathrm{H}_{2}$ : Firm Size, Cash Balance, Leverage, Profitability, and/or Firm Maturity is/are significant partial determinant of DPR.

$\mathrm{H}_{3 \mathrm{a}}$ : DPR is a significant determinant of Subsequent earning growth

$\mathrm{H}_{3 \mathrm{~b}}$ : DPR is not a significant determinant of Subsequent earning growth.

Model 1 will test $\mathrm{H}_{1 \mathrm{a}}, \mathrm{H}_{1 \mathrm{~b}}$, and $\mathrm{H}_{2}$, while Model 2 will test $\mathrm{H}_{3 \mathrm{a}}$ and $\mathrm{H}_{3 \mathrm{~b}}$. 


\section{RESULT AND DISCUSSION}

Table 1 shows the coefficients of Model 1. Only CASH and RETE has significance on determining DPR at 5\% level. As described in Table V.2, R-square of this model is 0.049. This means the Model 1 has only $4.9 \%$, which in turn means that all the variables account for $4.9 \%$ of DPR's variability, while $95.1 \%$ can be described by other factors not included in this model. As a consequence of using sample instead of population data in the regression, it's wiser to regard adjusted R-square instead of R-square. Thus, this model has only described $2.1 \%$ variability of DPR, while the other $97.9 \%$ are not

Table 1. Regression Coefficient of Model 1

coefficients $^{a}$

\begin{tabular}{|c|c|c|c|c|c|c|c|c|}
\hline \multirow{2}{*}{\multicolumn{2}{|c|}{ Model }} & \multicolumn{2}{|c|}{$\begin{array}{c}\text { Unstandardized } \\
\text { Coefficients }\end{array}$} & \multirow{2}{*}{$\begin{array}{c}\text { Standardized } \\
\text { Coefficients }\end{array}$} & \multirow[b]{2}{*}{$t$} & \multirow[b]{2}{*}{ Sig. } & \multicolumn{2}{|c|}{ Collinearity Statistics } \\
\hline & & $\mathrm{B}$ & Std. Error & & & & Tolerance & VIF \\
\hline \multirow[t]{6}{*}{1} & (Constant) & .132 & .292 & & .453 & .651 & & \\
\hline & $\mathrm{CASH}$ & .763 & .365 & .165 & 2.092 & .038 & .875 & 1.143 \\
\hline & RETE & .141 & .067 & .177 & 2.099 & .037 & .773 & 1.294 \\
\hline & SIZE & .005 & .022 & .020 & .243 & .809 & .772 & 1.295 \\
\hline & DER & .046 & .043 & .101 & 1.052 & .294 & .590 & 1.695 \\
\hline & ROA & -.001 & .004 & -.018 & -.218 & .828 & .839 & 1.192 \\
\hline
\end{tabular}

a. Dependent Variable: DPR

Table 2. Model Summary of Model 1

Model Summary

\begin{tabular}{|l|r|r|r|r|}
\hline Model & $\mathrm{R}$ & $\mathrm{R}$ Square & $\begin{array}{l}\text { Adjusted } \\
\text { R Square }\end{array}$ & $\begin{array}{r}\text { Std. Error of } \\
\text { the Estimate }\end{array}$ \\
\hline 1 & $.221^{\mathrm{a}}$ & .049 & .021 & .43788 \\
\hline
\end{tabular}

a. Predictors: (Constant), ROA, SIZE, RETE, CASH, DER

Table 3. ANOVA of Model 1

ANOVA ${ }^{\mathrm{b}}$

\begin{tabular}{|ll|r|r|r|r|r|}
\hline Model & & $\begin{array}{c}\text { Sum of } \\
\text { Squares }\end{array}$ & df & Mean Square & F & Sig. \\
\hline 1 & Regression & 1.819 & 5 & .364 & 1.904 & $.096^{3}$ \\
& Residual & 33.250 & 174 & .191 & & \\
& Total & 35.069 & 179 & & & \\
\hline
\end{tabular}

a. Predictors: (Constant), ROA, SIZE, CASH, RETE, DER

b. Dependent Variable: DPR 
described by this model. Analysis of Model 1 variance suggests a low F-ratio which is not significance at 5\% level. As a consequence, this model may not be used to predict DPR.

These results suggest that we will reject hypothesis $\mathrm{H} 1 \mathrm{a}$ and $\mathrm{H} 1 \mathrm{~b}$ and accept H2. Only CASH and RETE are statistically significant variable to DPR.

In relation with previous studies, this analysis provides several insights. Firstly, it contradicts the results by Parua and Gupta (2009) where Indian companies tend to pay less dividend when the company accumulated cash. In this study, Indonesian firms are found to be giving out dividend at higher DPR ratio when the cash balance is high. This finding is also consistent with the finding by Hakim (2007) and Prihantoro (2003): both authors have found out that Indonesian firms tend to pay dividend higher when the cash balance is high.

In addition to the research by DeAngelo et al. (2006), RETE is found to be also has influence on DPR (significant at 5\% level). Linear regression also proved that firms with higher maturity tend to pay higher dividend payout ratio. This is consistent with the Firm Life Cycle Theory by Mueller (1972) where high RETE suggests high DPR: the more mature a firm, the higher its dividend payout ratio.

Other variables are not found to be a significant determinant of DPR as suggested by the p-values. Profitability has no significance in determining DPR in this study while the study on Pakistani firms by Ahmed and Javid (2009) had found out that high profitability has high DPR. The research also used ROA as the measure of profitability. Leverage and Size has statistical significance in research by Smith and Watts (1992) yet has not effect in Indonesian firms as shown from this research. 
Regression coefficient of Model 2 is presented in Table 4. The result shows that DPR has positive relationship with SEG. An increase of 1 in DPR in the equation would increase SEG by 11.905 . R-square of this model is 0.216 , indicating that this model can account for $21.6 \%$ variability of Subsequent Earnings Growth. The F ratio of this model is 49.155 with p-value of below 0.001 far below the level of 5\%, pvalue for DPR as independent variable of SEG also below 5\%, indicating that there's a good chance to reject the null hypothesis of $\mathrm{H}_{1 b}$ thus accepting the hypothesis $\mathrm{H}_{3 \mathrm{a}}$ : DPR is a significant determinant of SEG.

Previous research done by Arnott and Asness (2003) also found out that high DPR translates to high Subsequent Earning Growth. Further research by Gwylim et al. (2006) on 10 major markets (namely France, Germany, Greece, Italy, Japan, Netherlands, Portugal, Spain,

Table 4. Regression Coefficient of Model 2

Coefficients ${ }^{\mathrm{a}}$

\begin{tabular}{|c|c|c|c|c|c|c|c|c|}
\hline \multirow{2}{*}{\multicolumn{2}{|c|}{ Model }} & \multicolumn{2}{|c|}{$\begin{array}{l}\text { Unstandardized } \\
\text { Coefficients }\end{array}$} & \multirow{2}{*}{$\begin{array}{l}\text { Standardized } \\
\text { Coefficients } \\
\text { Beta }\end{array}$} & \multirow[b]{2}{*}{$t$} & \multirow[b]{2}{*}{ Sig. } & \multicolumn{2}{|c|}{ Collinearity Statistics } \\
\hline & & B & Std. Error & & & & Tolerance & VIF \\
\hline & (Constant) & -3.897 & 1.021 & & -3.818 & .000 & & \\
\hline & DPR & 11.905 & 1.698 & .465 & 7.011 & .000 & 1.000 & 1.000 \\
\hline
\end{tabular}

a. Dependent Variable: SEG

Table 5. Model Summary of Model 2

Model Summary

\begin{tabular}{|l|r|r|r|r|}
\hline Model & R & R Square & $\begin{array}{c}\text { Adjusted } \\
\text { R Square }\end{array}$ & $\begin{array}{r}\text { Std. Error of } \\
\text { the Estimate }\end{array}$ \\
\hline 1 & $.465^{a}$ & .216 & .212 & 10.05520 \\
\hline
\end{tabular}

a. Predictors: (Constant), DPR

Table 6. ANOVA of Model 2

ANOVA'

\begin{tabular}{|ll|r|r|r|r|r|}
\hline Model & & \multicolumn{1}{|c|}{$\begin{array}{c}\text { Sum of } \\
\text { Squares }\end{array}$} & \multicolumn{1}{c|}{ df } & Mean Square & \multicolumn{1}{c|}{ F } & Sig. \\
\hline 1 & Regression & 4969.954 & 1 & 4969.954 & 49.155 & $.000^{3}$ \\
& Residual & 17997.040 & 178 & 101.107 & & \\
& Total & 22966.994 & 179 & & & \\
\hline
\end{tabular}

a. Predictors: (Constant), DPR

b. Dependent Variable: SEG 
Switzerland, and UK) also found out the same: high DPR translates to high SEG. Gwylim et al. (2006) also concludes that large reinvestment of retained earnings will lead to faster real dividend growth.

\section{CONCLUSION}

Dividend payout ratio has shown to affect the subsequent earnings growth positively. Investment managers may choose to compose their portfolio using high dividend payout ratio firms because the higher payout ratio, the higher expected earnings growth. Firms with high DPR have high expected earnings growth. The result of this research also confirms the previous research by Arnott and Asness (2003) regarding subsequent earnings growth.

Of five variables tested, only two variables (CASH and RETE) that has statistical significance in determining dividend payout ratio in Indonesian firms. Higher Retained Earnings to Shareholder's Equity ratio indicates a high DPR. If the claim by DeAngelo et al regarding high RETE translate to mature firm holds true, it also confirms the lifecycle theory proposed by Mueller: firms in growth state holds back more earnings while mature firms pays more dividend. We also confirmed that Cash Balance affect the DPR positively. Higher Cash Balance translates to higher DPR, thus confirming Parua \& Gupta's (2009) claim. This provides some insights to the dividend policy in Indonesia: dividend payers tend to have large portion of cash in their asset composition.

This research suggests that investment managers should regard dividend payout ratio as signaling of earning growth. By comparing to the earnings growth of non-payer firms, investors would have an insight on whether dividend payer or non-payer has the most earnings growth.

As R-square of both model suggests, There's a room for improvement on how DPR and SEG are predicted. Other variables may be introduced to explain the DPR and SEG.

By using longer-term data instead of only one year subsequent 
earnings growth to 5 or 10 years as Arnott and Asness suggested will provide longer-term growth research on earnings growth. Currently such data is not available to the public (dividend data is only recorded in IDX Book of Statistics from 2002 to date).

\section{REFERENCES}

Ahmed, Hafeez, Attiya Y. Javid. 2009. "The Determinants of Dividend Policy in Pakistan." International Research Journal of Finance and Economics. Issue 29.

Anil, Kanwal, Sutaja Kapoor. 2008. "Determinants of Dividend Payout Ratios-A Study of Indian Information Technology Sector." International Research Journal of Finance and Economics Issue 15:63-71

Arnott, R.D., and C.S. Asness. 2003. "Surprise! Higher Dividends = Higher Earning Growth" Financial Analysts Journal, vol. 59, no. 1 (January/February):70-87

Baker, H. Kent, Gail E. Farrelly, and Richard B. Edelman. 1985. "A Survey of Management Views on Dividend Policy." Financial Management 14:3,78-84.

Baker, Malcolm, and Jeffrey Wurgler. 2004. "A Catering Theory of Dividends." Journal of Finance 59:3,1125-1165.

Baker, Malcolm, and Jeffrey Wurgler. 2004. "Appearing and Disappearing Dividends: The Link to Catering Incentives." Journal of Financial Economics 73:2,271-288.

Baker, Kent. 2009. Dividends and Dividend Policy, John Wiley \& Sons, Inc., New Jersey

Black, Fischer. 1976. "The Dividend Puzzle." Journal of Portfolio Management 2:2,5-8.

DeAngelo, Harry, Linda DeAngelo, and Rene M.Stulz. 2006. "Dividend Policy and the Earned/Contributed Capital Mix: A Test of the Lifecycle Theory." Journal of Financial Economics 81:2,227-254.

Fama, Eugene F., and Kenneth R. French .2001. "Disappearing Dividends: Changing Firm Characteristics or Lower 
Propensity to Pay?" Journal of Financial Economics 60:1,343.

Field, Andy. 2005. Discovering Statistics using SPSS, $2^{\text {nd }}$ Edition, Sage Publication Ltd., London.

Gwilym, Owain ap, James Seaton, Karina Suddason, and Stephen Thomas. 2006. "International Evidence on the Payout Ratio, Earnings, Dividends, and Returns." Financial Analysts Journal 62:1 36-52

Hakim, Farih Rahman. 2007. "Analisis Faktor-faktor yang Berpengaruh Terhadap Rasio Pembayaran Dividen pada Perusahaan Manufaktur yang Membagikan Dividen dan Terdaftar di BEJ Tahun 2003-2005. Jakarta.Available: http://digilib.unnes.ac.id/gsdl/collect/skripsi/archives/HASHaf de/c3531773.dir/doc.pdf

Hall, Bronwyn H. 1987. "The Relationship Between Firm Size and Firm Growth in the US Manufacturing Sector". The Journal of Industrial Economics. 35:4, 583-606.

Lintner, John. 1956. "Distribution of Incomes of Corporations among Dividends, Retained Earnings and Taxes." American Economic Review 46:2,97-113.

Miller, Merton H., and Franco Modigliani. 1961. "Dividend Policy, Growth, and the Valuation of Shares." Journal of Business $34: 4,411-433$.

Mueller, Dennis C.1972. “A Life Cycle Theory of the Firm,” Journal of Industrial Economics. 20:3,199-219.

Parua, Anupam, Arindam Gupta. 2009. "DIVIDEND HISTORY AND DETERMINANTS IN SELECTED INDIAN COMPANIES: A STUDY DURING 1993-'94 TO 2004-'05". The Australasian Accounting Business \& Finance Journal. Vol 3, No 4.

Prihantoro. 2003. "Estimasi Pengaruh Dividend Payout Ratio pada Perusahaan Publik Indonesia". Jurnal Ekonomi \& Bisnis. No 1, Jilid 8

Smith, Clifford W., and Ross L. Watts. 1992. "The Investment Opportunity Set and Corporate Financing, Dividend, and 
Compensation Policies." Journal of Financial Economics 32:3,263-292.

U.S. Securities and Exchange Commission. 2010. Ex-dividend Dates, Available: http://www.sec.gov/answers/dividen.htm [2010, August 28] 